\title{
Mammary Carcinoma Cell Derived Cyclooxygenase 2 Suppresses Tumor Immune Surveillance by Enhancing Intratumoral Immune Checkpoint Activity
}

Nune Markosyan ${ }^{1}$, Edward P Chen ${ }^{1}$, Rebecca A Evans², Victoire Ndong ${ }^{1}$, Robert H Vonderheide ${ }^{2,3}$ and Emer M Smyth ${ }^{1 *}$

\begin{abstract}
Introduction: Systemic inhibition of the inflammatory enzyme cyclooxygenase (COX) 2 decreases the risk of breast cancer and its recurrence. However, the biology of COX-2 in the multicellular tumor microenvironment is poorly defined.

Methods: Mammary tumor onset and multiplicity were examined in ErbB2 transgenic mice that were deficient in mammary epithelial cell COX-2 (COX-2 $\left.2^{\mathrm{MEC}} \mathrm{KO}\right)$ compared to wild type (WT) mice.

Tumors were analyzed, by real time PCR, immune-staining and flow cytometry, for proliferation, apoptosis, angiogenesis and immune microenvironment. Lentiviral shRNA delivery was used to knock down (KD) COX-2 in ErbB2-transformed mouse breast cancer cells (COX-2KD), and growth as orthotopic tumors was examined in syngenic recipient mice, with or without depletion of $\mathrm{CD}^{+}$immune cells.

Results: Mammary tumor onset was delayed, and multiplicity halved, in COX-2 ${ }^{\mathrm{MEC}} \mathrm{KO}$ mice compared to WT. COX-2 ${ }^{\mathrm{MEC}} \mathrm{KO}$ tumors showed decreased expression of Ki67, a proliferation marker, as well as reduced VEGFA, its receptor VEGFR2, endothelial NOS and the vascular endothelial marker CD31, indicating reduced tumor vascularization. COX-2 ${ }^{\mathrm{MEC}} \mathrm{KO}$ tumors contained more $\mathrm{CD} 4^{+} \mathrm{T}$ helper $\left(T_{h}\right)$ cells and $\mathrm{CD} 8^{+}$cytotoxic immune cells $(C T L)$ consistent with increased immune surveillance. The ratio of $T_{h}$ markers Tbet $\left(T_{h} 1\right)$ to GATA3 $\left(T_{h} 2\right)$ was higher, and levels of Retnla, a M2 macrophage marker, lower, in COX-2 ${ }^{\mathrm{MEC}} \mathrm{KO}$ tumor infiltrating leukocytes compared to $W T$, suggesting a prevalence of pro-immune $T_{h} 1$ over immune suppressive $T_{h} 2$ lymphocytes, and reduced macrophage polarization to the immune suppressive M2 phenotype. Enhanced immune surveillance in COX-2 ${ }^{\text {MEC }}$ KO tumors was coincident with increased intratumoral CXCL9, a T cell chemoattractant, and decreased expression of T lymphocyte co-inhibitory receptors CTLA4 and PD-1, as well as PD-L1, the ligand for PD-1. PD-L1 was also decreased in IFNy-treated COX-2KD mouse mammary cancer cells in vitro and, compared to control cells, growth of COX-2KD cells as orthotopic tumors in immune competent mice was markedly suppressed. However, robust growth of COX-2KD tumor cells was evident when recipients were depleted of CD8 ${ }^{+}$cells.

Conclusions: The data strongly support that, in addition to its angiogenic function, tumor cell COX-2 suppresses intratumoral cytotoxic $\mathrm{CD}^{+}$immune cell function, possibly through upregulation of immune checkpoints, thereby contributing to tumor immune escape. COX-2 inhibition may be clinically useful to augment breast cancer immunotherapy.
\end{abstract}

Keywords: breast cancer, immune modulation, tumor microenvironment, cytotoxic immune cells, PD-L1

\footnotetext{
* Correspondence: emsmyth@mail.med.upenn.edu

'Institute for Translational Medicine and Therapeutics, Smilow Center for

Translational Research, 3400 Civic Center Blvd, Philadelphia, PA 19104, USA

Full list of author information is available at the end of the article
} 


\section{Introduction}

The inducible form of cyclooxygenase (COX), COX-2, and one of its pro-inflammatory products, prostaglandin (PG) $E_{2}$, are strongly implicated in a range of human cancers including breast cancer [1,2]. Global deletion or pharmacological inhibition of COX-2 suppressed tumorigenesis in mice [3,4] and humans [5]. $\mathrm{PGE}_{2}$ signals through multiple pro-tumor pathways, including PI3K/ AKT, RAS-MAPK/ERK and Gs-axin-ß-catenin signaling, to increase tumor cell survival, inhibit apoptosis, increase cancer cell motility, stimulate angiogenesis and inhibit immune surveillance [6].

In the last decade it has become clear that the tumor microenvironment is critical for tumors to survive and progress. In addition to vascular supply, the interplay of tumor cells with non-malignant cells in the stroma provides growth, survival and motility advantages. A central part of the tumor microenvironment is infiltration of immune cells, which can positively or negatively influence tumor progression depending on their differentiation $[7,8]$. Tumor rejection is favored through $T$ helper $1\left(T_{h} 1\right)$ derived cytokines that drive antigen-presenting and proimmune M1 macrophage functions, and by the direct tumoricidal actions of $\mathrm{CD} 8^{+}$cytotoxic $\mathrm{T}$ lymphocytes (CTLs) and natural killer (NK) cells [6]. However, as tumors progress, soluble mediators and cellular interactions are thought to reprogram immune cells to type 2 functions so that $T_{h} 2$ lymphocyte-derived cytokines polarize macrophages to the M2 phenotype to suppress CTLs, promote angiogenesis and support tumor growth $[6,9]$. In breast cancer, poor prognosis is associated with elevated $\mathrm{T}_{\mathrm{h}} 2$ lymphocytes and tumor-associated macrophages (TAM), while $\mathrm{T}_{\mathrm{h}} 1$ lymphocytes, CTLs and NKs correlate with enhanced survival $[8,10]$, raising intense interest in therapeutic approaches to modify the tumor immune microenvironment. COX-2-derived $\mathrm{PGE}_{2}$ has emerged as a tumor-derived mediator that contributes to development of immune tolerance [11-13]. Several studies report the association of tumor COX-2 with infiltrating $\mathrm{T}$ cells, dendritic cells, myeloid derived suppressor cells and macrophages [14-17], while $\mathrm{PGE}_{2}$ has been linked to immune suppression in hepatocellular carcinoma [18], lung [19], ovarian $[20]$ and breast $[14,15]$ cancers. The mechanisms through which $\mathrm{COX}-2 / \mathrm{PGE}_{2}$ suppress immune function are poorly defined; however, $\mathrm{PGE}_{2}$ suppressed the ability of mature CTLs to kill murine plasmocytoma cells [21] and inhibited $\mathrm{T}_{\mathrm{h}} 1$ generation of interferon $\gamma$ (IFN $\gamma$ ) $[22,23]$, a cytokine that is critical to sustain anti-tumor immune function [6,24].

We reported that selective deletion of mammary epithelial cell (MEC) COX-2 (COX-2 ${ }^{\mathrm{MEC}} \mathrm{KO}$ ) delayed carcinogeninduced mammary tumor onset coincident with enhanced markers of anti-tumor type 1 immunity [17]. Chemical carcinogens are generally not, however, considered significant in human breast cancer etiology; therefore, in the current study, we investigated the role of tumor cell COX-2derived mediators in ErbB2 (HER-2/neu)-induced mammary tumorigenesis. ERBB2 gene amplification or overexpression of the HER-2 protein has been identified in $25 \%$ to $34 \%$ of human breast cancers [25,26]. ErBb2 mouse models show remarkable morphological resemblance to some forms of human breast cancer and accurately recapitulate the hallmark changes associated with the early stages of human breast cancer [27]. In COX-2 ${ }^{\mathrm{MEC}} \mathrm{KO}$ mice transgenic for an activated ErbB2 mutant, we determined delayed tumor onset and reduced tumor multiplicity, as well as reduced tumor vascularization, compared to wild type (WT). Deletion of COX-2 in tumor cells also significantly impaired maintenance of pro-tumorigenic lymphoid and myeloid cell functions thereby facilitating enhanced immune surveillance.

\section{Methods}

\section{Mice and tumor tissue collection}

All procedures were conducted in accordance with National Institutes of Health regulations and were approved by the Institutional Animal Care and Use Committee of the University of Pennsylvania.

Floxed COX-2 mice, generated by flanking the COX-2 gene between introns 5 and 8 with loxP sites (COX$2^{\text {flox/flox }}$ ), were backcrossed fully ( $>9$ generations) onto an FVB background and are denoted as wild type (WT) mice. COX-2 $2^{\text {flox/flox }}$ mice were crossed with FVB mice expressing Cre-recombinase under control of the mouse mammary tumor virus (mmtv) promoter $\left(\mathrm{Cre}^{\mathrm{mmtv}}\right)$, which is used widely to target transgene expression to MEC. The resulting mice were termed COX $-2^{\mathrm{MEC}} \mathrm{KO}$ and their characterization is described in our previous work [17]. WT and COX-2 ${ }^{\mathrm{MEC}} \mathrm{KO}$ were crossed with mice transgenic for the ErbB2 (HER2/c-neu) oncogene carrying Eactivating $\mathrm{Val}^{664}$ to $\mathrm{Glu}^{664}$ mutation (Jackson Laboratory, Bar Harbor, ME, USA), also expressed under the control of mmtv promoter. Genotype verification was performed by conventional PCR using primers listed in Table 1.

\section{Table 1 Genotyping primer sequences}

\begin{tabular}{ll}
\hline Gene & Forward (F) and Reverse (R) primer sequences \\
\hline COX-2 & F:TGA GGC AGA AAG AGG TCC AGC CT \\
& R:ACC AAT ACT AGC TCA ATA AGT GAC \\
Cre $^{\text {mmtv }}$ & F:TCG ATG CAA CGA GTG ATG AGG \\
& R:ACG AAC CTG GTC GAA ATC AGT \\
Erbb2 & F:GGACATCCAGGAAGTTCAGGGTAC \\
& R:ACAGGAGCCAGTTGGTATTCTTG \\
\hline
\end{tabular}


Mice were palpated weekly and considered tumor bearing if a palpable mammary mass persisted for more than one week. On necropsy, tumors were counted and isolated from surrounding tissues, after which they were either frozen and stored at $-80^{\circ} \mathrm{C}$ for RNA extraction or fixed in Prefer (Anatech, Battle Creek, MI, USA) overnight and paraffin embedded or digested to obtain single cell suspension for flow cytometry and microbead separation. For tissue digestion, tumors were washed with (D)MEM/F12 + 5\% fetal bovine serum (FBS) + gentamycin $50 \mathrm{mg} / \mathrm{ml}$, minced and placed in digestion buffer consisting of 9 parts of wash buffer +1 part collagenase/hyaluronidase (StemCell Technologies, Vancouver, BC Canada). After two hours shaking at $37^{\circ} \mathrm{C}$, the suspensions were centrifuged at $1,000 \mathrm{rpm}$ for five minutes. Pellets were washed and treated with red cell lysis buffer ( 1 part $\mathrm{HBSS}+2 \% \mathrm{FBS}+3$ parts $\mathrm{NH}_{4} \mathrm{Cl}$ ) and then with Trypsin-ethylenediaminetetraacetic acid (EDTA) $0.25 \%$ (Gibco, Grand Island, NY, USA), followed by Dispase and DNase (StemCell Technologies). Thereafter, cell pellets were passed through a $40 \mu \mathrm{m}$ cell strainer, counted and re-suspended either in fluorescence-activated cell sorting (FACS) buffer for flow cytometry (description below) or in degassed MACS buffer $(\mathrm{PBS}+0.5 \% \mathrm{BSA}+2 \mathrm{mM}$ EDTA $)$ for positive selection of $\mathrm{CD} 45^{+}$cells using CD45-microbeads (Miltenyi Biotec, Auburn, CA, USA) according to the manufacturer's instructions.

\section{NAF mammary tumor cell line culture, transduction, and treatments}

The NAF tumor cell line, which was generated from mammary tumors of ErbB2-transgenic mice, was kindly provided by Dr. Lewis Chodosh (University of Pennsylvania). NAF were cultured in (D)MEM medium containing $10 \%$ FBS, 1\% L-glutamine and 1\% penicillin/streptomycin. For viral transduction, 15,000 cells/well were plated on 96-well plates. Mission plKO.1-puro Transduction Lentiviral Particles $(20 \mu \mathrm{l})$, carrying either non-target control small hairpin RNA (shRNA) or COX-2 shRNA (Sigma, St. Louis, $\mathrm{MO}$, USA), at $1 \times 10^{7} \mathrm{TU} / \mathrm{ml}$ were added to the wells with $8 \mu \mathrm{g} / \mathrm{ml}$ protamine sulfate. After 18 hours, lentiviral particles were removed and cells kept in medium containing $2 \mu \mathrm{g} / \mathrm{ml}$ puromycin (Sigma) to select for transduced cells. COX-2 knock down in COX-2 shRNA transduced NAF cells (NAF COX-2KD) compared to non-target shRNA transduced cells (NAF nt) was verified by Q-PCR. Cells were serum starved for 24 hours and then treated with $10 \mathrm{ng} / \mathrm{ml}$ IFN $\gamma$ (PeproTech, Rocky Hill, NJ, USA ),

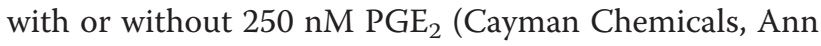
Arbor, MI, USA). Fresh IFN $\gamma$ and $\mathrm{PGE}_{2}$ were added 24 hours later, and cells were harvested (0.25\% TrypsinEDTA) after 48 hour treatment, washed and re-suspended in FACS buffer for flow cytometry analysis.
Bone marrow-derived macrophage isolation and culture Bone marrow-derived macrophages (BMDM) were isolated as described [28]. Femurs from female mice were flushed with (DMEM and cells pelleted $(1,000 \mathrm{rpm})$ and incubated at $37^{\circ} \mathrm{C}$ for 24 hours in (DMEM containing $10 \%$ FBS, $1 \%$ L-glutamine, and $1 \%$ penicillin/streptomycin. Non-adherent cells were collected and plated in L929 cell-conditioned medium (LCCM). To make LCCM, medium collected from L929 cells (American Type Culture Collection, Manassas, VA, USA), that were split 1:5 and grown to confluency, was mixed 1:5 with (DMEM with 10\% FBS, 1\% L-glutamine, and 1\% penicillin/streptomycin. Purity (approximately 99\%) was verified by flow cytometry for F4/80 and CD11b (not shown $)$. BMDM were plated $\left(0.5 \times 10^{6}\right.$ cells/well $)$ in LCCM. At 100\% confluency, media was replaced with (DMEM. After 24 hours, cells received vehicle, or M1 polarizing mix (100 ng/ml lipopolysaccharide (LPS; Sigma) and $20 \mathrm{ng} / \mathrm{ml}$ IFN $\gamma$ (Peprotech)), or M2 polarizing mix (20 ng/mL IL-4 and $10 \mathrm{ng} / \mathrm{mL}$ IL-13; Peprotech), with or without $250 \mathrm{nM} \mathrm{PGE} 2$ (Cayman Chemicals). Supernatants were removed 18 hours later and cells lysed for RNA isolation.

\section{Real Time RT-PCR}

Total RNA from tumors and cells was isolated (RNeasy, Qiagen, Germantown, MD, USA), and reverse transcribed (TaqMan Reverse Transcriptase, Applied Biosystems, Carlsbad, CA, USA), according to the manufacturer's instructions. Real time quantitative (Q)-PCR of all genes, including $18 \mathrm{~S}$ ribosomal RNA, was performed using inventoried gene expression assays and TaqMan Universal PCR Master Mix from Applied Biosystems. PCR products were detected in ABI-PRISM 7900 sequence detection systems (Applied Biosystems). Results were analyzed using the comparative $\mathrm{Ct}$ method, and normalized to $18 \mathrm{~S}$ RNA.

\section{Immunohistochemistry}

Paraffin embedded tumor tissues were sectioned $(4 \mu \mathrm{m})$. After de-paraffinization and rehydration, endogenous peroxidase was blocked with $3 \%$ hydrogen peroxide. Heat induced epitope retrieval was performed with $1 \mathrm{mM}$ EDTA (Invitrogen, Grand Island, NY, USA). After overnight blocking at $4{ }^{\circ} \mathrm{C}$ with $5 \%$ donkey serum (Sigma) + $0.1 \%$ Triton $100 \times$ (Sigma), sections were incubated with primary antibodies overnight at $4^{\circ} \mathrm{C}$ as follows: anti-Ki67 (Abcam, Cambridge, MA, USA,1:50 dilution), anti-CD31 (Abcam, 1:200 dilution) or anti-CXCL9 (Aviva Systems Biology, San Diego, CA, USA 1:125 dilution). Thereafter, the Polink-2 HRP Plus AEC System for Immunohistochemistry (Golden Bridge International, Inc, Mukillteo, WA, USA) was used, according to the manufacturer's instructions. Slides were then counterstained with hematoxylin (Vector Laboratories, Burlingame, CA, USA), and 
mounted (Aqua-Mount; Lerner Laboratories, Pittsburgh, PA, USA). Images were taken with a Nikon Eclipse E600 microscope using ACT-1 imaging program (Nikon Instruments Inc., Hicksville, NY, USA).

\section{Flow cytometry}

Single cell suspensions from tumor digestions (above) were centrifuged, washed and re-suspended in FACS buffer (PBS + $2 \% \mathrm{FBS}+1 \mathrm{mM}$ EDTA $+0.01 \%$ sodium azide), $1 \times 10^{6} \mathrm{cell} / 100 \mu \mathrm{l} /$ tube. After a five minute incubation with rat anti-mouse CD16/CD32 (Mouse BD Fc Block, BD Pharmingen, Franklin Lakes, NJ, USA), $1 \mu \mathrm{g} / \mathrm{ml}$ of fluorescein isothiocyanate (FITC) conjugated anti-CD3, PE conjugated anti-CD4, and AF647 conjugated anti-CD8a, or PE conjugated anti-F4/80 and AF647 conjugated anti-CD86 antibodies (Invitrogen) were added. OneComp eBeads (eBioscience, San Diego, CA, USA) were incubated with anti-CD3 or anti-CD4 or anti-CD8a antibodies to perform compensation for spectral overlap. NAF COX-2KD and NAF nt $\left(1 \times 10^{6}\right.$ cell/ $\left.100 \mu \mathrm{l}\right)$, were incubated with PE conjugated anti-PD-L1 antibody (Biolegend, San Diego, CA USA). After a 30-minute incubation, cells were washed and re-suspended in $500 \mu \mathrm{l}$ FACS buffer. Unstained tumor cells and cells incubated with isotype control rat antimouse antibody were used as negative controls. FACS analysis was performed on a BD FACSCalibur machine (BD Biosciences, San Jose, CA, USA). Data was analyzed using FlowJo Research Flow Cytometry Analysis Software (TreeStar, Ashland, OR USA).

\section{Orthotopic tumor growth and $\mathrm{CD}^{+}$depletion}

NAF COX-2KD and NAF nt tumor cells were injected into the \#4 and \#9 mammary glands $\left(1 \times 10^{6}\right.$ cells/gland in $100 \mu \mathrm{l}$ Hanks Balanced Salt Solution) of normal WT female mice between 8 to 14 weeks of age. Orthotopic tumor volume was determined weekly using standard caliper measurement. For CD8+ depletion experiments, mice were injected intraperitoneally with $200 \mu \mathrm{g}$ of an anti-CD8 or isotype control antibody (BioXCell, West Lebanon, $\mathrm{NH}$, USA), four days and again two days prior to injection of tumor cells, and then twice weekly for a further four weeks. Depletion of CD8+ cells was confirmed by flow cytometry of erythrocyte lysed whole blood (ACK Lysing Buffer, Invitrogen), four days and again four weeks after tumor cell injections.

\section{Statistical analysis}

Statistical analyses were performed using Prism (GraphPad Software, Inc., La Jolla, CA, USA). As appropriate, comparisons were made using logrank analysis, unpaired $t$-test (with Welch's correction when variances were significantly different by F-test), Mann Whitney test (when the data distribution was not normal), or, for multiple group comparisons, analysis of variance (ANOVA) followed by Bonferroni's multiple comparison test.

\section{Results \\ Tumor onset, development, and vascularization in WT and COX-2 ${ }^{\mathrm{MEC}} \mathrm{KO}$ mice}

The current investigation was designed to study the role of MEC COX-2 in mammary tumor development, with the goal of elucidating whether and how targeted inhibition of COX-2 in epithelial cells affects the disease. In our previous study we confirmed COX-2 deletion in MEC isolated from COX-2 ${ }^{\mathrm{MEC}} \mathrm{KO}$ mice by Q-PCR and Western blotting, and loss of $\mathrm{PGE}_{2}$ generation by COX$2^{\mathrm{MEC}} \mathrm{KO}$ cells was established by mass spectrometry [17]. COX-2 expression and $\mathrm{PGE}_{2}$ production were unchanged in peripheral macrophages isolated from COX $-2{ }^{\mathrm{MEC}} \mathrm{KO}$ compared to WT confirming the selectivity of the deletion [17]. In the current study, tumor onset was significantly delayed in $\mathrm{COX}-2^{\mathrm{MEC}} \mathrm{KO}$ mice compared to their WT littermates (Figure 1A). On necropsy, COX-2 ${ }^{\mathrm{MEC}} \mathrm{KO}$ mice had significantly fewer tumors compared to WT (Figure 1A). Consistent with these observations, cell proliferation appeared higher in WT tumors, as indicated by higher levels of mRNA for the proliferation marker Ki67 in WT compared to COX-2 ${ }^{\mathrm{MEC}} \mathrm{KO}$ tumors (Figure 1B). Markers for apoptosis (caspase3) and autophagy (Lc3) were not different between the two genotypes (Figure 1B). Abundant expression of $\mathrm{Ki} 67$ protein in WT, but not COX$2^{\mathrm{MEC}} \mathrm{KO}$, tumors was confirmed by immunohistochemistry (Figure 1C).

Q-PCR analysis of tumors revealed lower expression levels of CD31, an endothelial marker, endothelial (e) NOS, the angiogenic factor VEGFA and its receptor VEGFR2 (Figure 2A), in COX-2 ${ }^{\mathrm{MEC}} \mathrm{KO}$ compared to WT. Although no difference was observed in mRNA levels of the lymphangiogenic factor VEGFC, its receptor VEGFR3 was significantly lower in COX-2 ${ }^{\mathrm{MEC}} \mathrm{KO}$ tumors (Figure 2A). Immunostaining for CD31 revealed a denser blood vessel network in WT tumors, confirming suppressed angiogenesis in $\mathrm{COX}-2^{\mathrm{MEC}} \mathrm{KO}$ tumors (Figure 2B).

\section{Subpopulations and phenotypes of tumor infiltrating immune cells in WT and COX-2 ${ }^{\mathrm{MEC}} \mathrm{KO}$ tumors}

WT and COX-2 ${ }^{\mathrm{MEC}} \mathrm{KO}$ tumors were analyzed by flow cytometry and Q-PCR to compare the populations of infiltrating immune cells and their phenotypes. By flow cytometry, there was no difference in the total number of $\mathrm{F} 4 / 80^{+} \mathrm{TAMs}$ between WT and COX- $2^{\mathrm{MEC}} \mathrm{KO}$ tumors (Figure $3 \mathrm{~A}$ ). COX-2 ${ }^{\mathrm{MEC}} \mathrm{KO}$ tumors did, however, have significantly higher numbers of $\mathrm{CD} 3^{+} \mathrm{CD} 4^{+}$cells, a population that includes $T_{h} 1, T_{h}$, and regulatory $T\left(T_{\text {reg }}\right)$ 

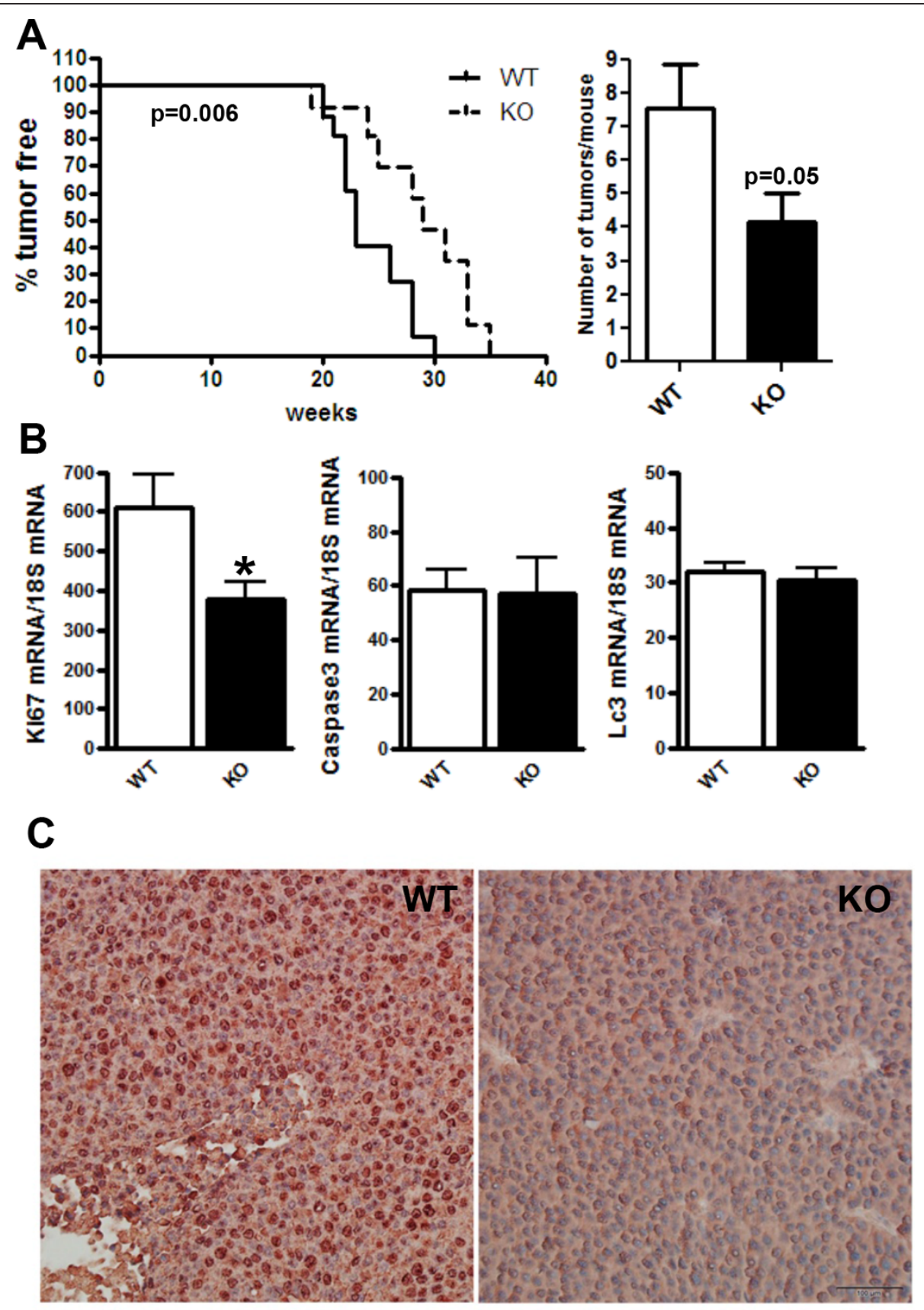

Figure 1 Tumor onset, multiplicity and cell proliferation were suppressed in COX-2 ${ }^{\mathrm{MEC}} \mathrm{KO}$ tumors. COX-2 ${ }^{\mathrm{MEC}} \mathrm{KO}$ tumors are denoted as KO. (A) Percent of tumor free mice against weeks of age. Mean tumor free time for COX-2 ${ }^{\text {MEC }}$ KO mice was 29 weeks versus 23 weeks for WT (left graph, $n=13$ to 19). The right graph shows tumor multiplicity as number of tumors per mice at necroscopy $(n=14$ to 18$)$. (B) Gene expression levels of Ki67 (proliferation), Caspase3 (apoptosis) and Lc3 (autophagy) in whole tumors by Q-PCR ( $n=8$ to 18). (C)

Immunohistochemistry staining for Ki67 (dark red-brown) in sections of paraffin embedded WT and COX-2 ${ }^{\text {MEC }}$ KO tumors (image shown is representative of $n=4$ ). Cell nuclei are counterstained with hematoxylin. The bar on the KO panel indicates 20x magnification. Data in column graphs are mean \pm sem. $P$ values are compared to $W T$; ${ }^{*} P<0.05$. COX, cyclooxygenase; KO, knock out; WT, wild type.

cells, as well as $\mathrm{CD}^{+} \mathrm{CD} 8^{+} \mathrm{CTLs}$ and $\mathrm{CD}^{-} \mathrm{CD} 8^{+}$cells, encompassing NK and dendritic cells (Figure 3A). To further define their functional identify, tumor-infiltrating leukocytes (TILs) were isolated using magnetic microbeads coated with a pan-leukocyte marker CD45 and cells analyzed by Q-PCR for phenotypic markers and cytokines (Figure 3B). The ratio of Tbet $\left(\mathrm{T}_{\mathrm{h}} 1\right.$ marker)/GATA3 $\left(\mathrm{T}_{\mathrm{h}} 2\right.$ marker) tended to be higher in $\mathrm{COX}-2^{\mathrm{MEC}} \mathrm{KO}$ tumors 

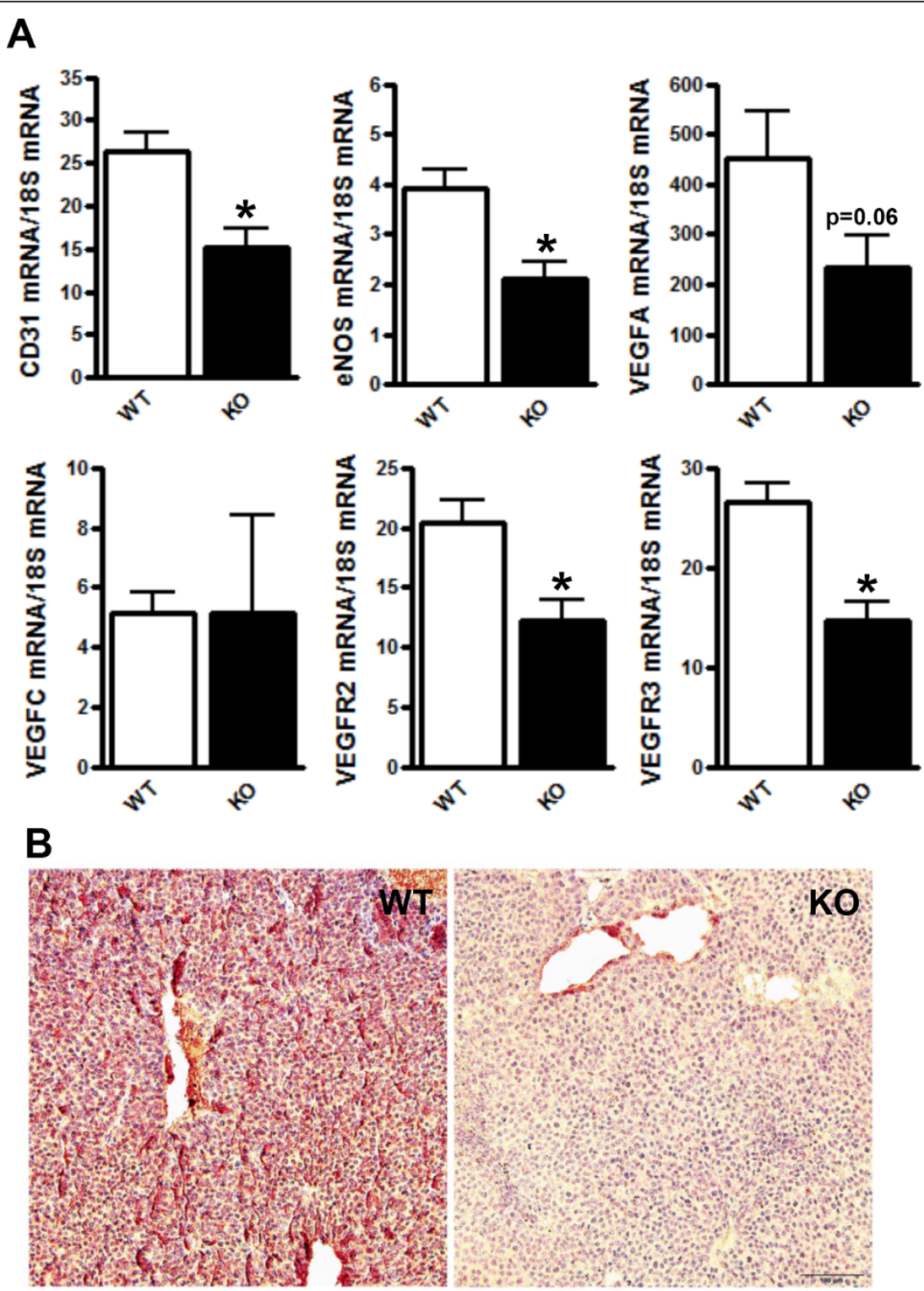

Figure 2 Angiogenesis was suppressed in COX-2 ${ }^{\mathrm{MEC}} \mathrm{KO}$ tumors. COX-2 ${ }^{\mathrm{MEC}} \mathrm{KO}$ tumors are denoted as KO. (A) Gene expression levels for CD31, eNOS, VEGFA, VEGFC, VEGFR2 and VEGFR3 in whole tumors by Q-PCR. Data are mean \pm sem of $n=8$ to 18. $P$ values are compared to WT. ${ }^{*} P<0.05$. (B) Immunohistochemistry staining for CD31 (dark red-brown) in sections of paraffin embedded WT and COX-2 ${ }^{\mathrm{MEC}} \mathrm{KO}$ tumors (image is representative of $n=6$ ). Cell nuclei are counterstained with hematoxylin. The bar on the KO panel indicates 20x magnification. COX, cyclooxygenase; KO, knock out; WT, wild type.

compared to WT (Figure 3B), suggesting a prevalence of $\mathrm{CD}^{+} \mathrm{CD}^{+} \mathrm{T}_{\mathrm{h}} 1$ over $\mathrm{T}_{\mathrm{h}} 2$ lymphocytes, when MEC COX2-derived mediators are absent. Further, mRNA levels for either Tbet alone or the Tbet/GATA3 ratio were significantly correlated with CD4 mRNA in COX-2 ${ }^{\mathrm{MEC}} \mathrm{KO}$, but not WT, tumors (data not shown). Gene expression of FoxP3, a marker for $\mathrm{T}_{\text {reg, }}$, was not altered and there was no difference in mRNA for macrophage type 1 cytokines TNF $\alpha$ and IFN $\gamma$ or an M1 macrophage marker CD86, in $\mathrm{CD} 45^{+}$TILs, suggesting no major change in M1 polarization in this disease model. COX-2-derived $\mathrm{PGE}_{2}$ has been implicated in driving the immune suppressive phenotype typically associated with TAM [6]. Indeed, exogenous $\mathrm{PGE}_{2}$ treatment significantly increased the expression of M2 marker Arginase 1, a key enzyme in suppression of $\mathrm{T}$ cell function, in both M1 and M2 polarized bone-marrow derived macrophages (Figure $3 \mathrm{C}$ ). In tumors, although arginase 1 mRNA levels were similar in TILs from COX$2^{\mathrm{MEC}} \mathrm{KO}$ and WT tumors, another M2 marker, Retnla, was significantly decreased in COX-2 ${ }^{\mathrm{MEC}} \mathrm{KO}$ (Figure $3 \mathrm{~B}$ ). Taken as a whole, our flow cytometry, immune staining and $\mathrm{CD} 45^{+}$cell expression analysis indicates that absence 

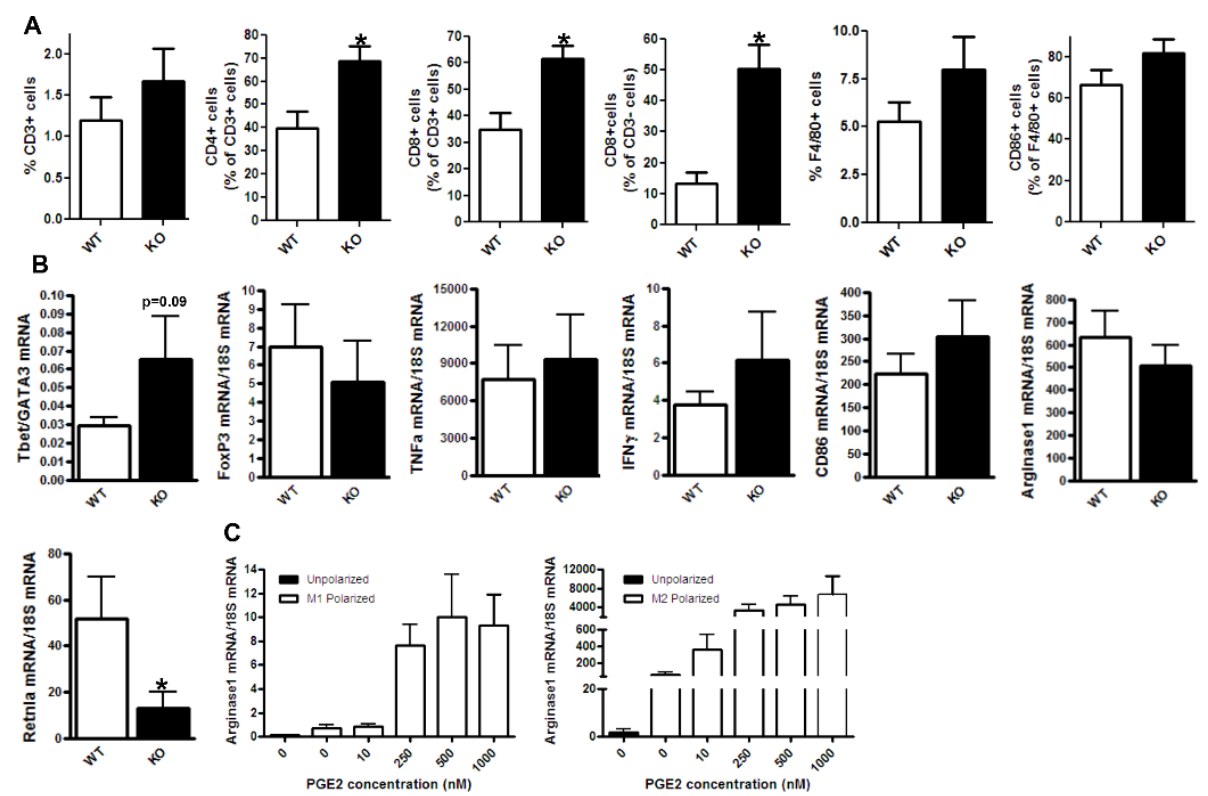

Figure 3 Deletion of mammary epithelial COX-2 modified tumor infiltrating cell phenotype. COX-2 ${ }^{\mathrm{MEC}} \mathrm{KO}$ tumors are denoted as $\mathrm{KO}$ (A) Flow cytometry analysis of tumor associated lymphocytes and macrophages ( $n=7$ to 10). (B) Gene expression levels measured by Q-PCR in $\mathrm{CD}_{4} 5^{+}$tumor infiltrating leukocytes (TILs) isolated from whole tumors by microbead separation ( $n=6$ to 7). (C) Gene expression levels measured by Q-PCR in unpolarized, M1 polarized or M2 polarized bone marrow derived macrophages, treated without or with $\mathrm{PGE}_{2}(n=8)$. Data are mean \pm sem. $P$ values are compared to $W T ;{ }^{*} p<0.05$. COX, cyclooxygenase; KO, knock out; $P G E_{2}$, prostaglandin $E_{2} ; W T$, wild type.

of epithelial COX-2-derived mediators augments $\mathrm{T}_{\mathrm{h}} 1$ and cytotoxic immune function and reduces immune suppressive macrophage function in the mammary tumor microenvironment.

\section{COX-2 may enhance immune tolerance through suppression of $\mathrm{T}$ cell recruitment and activation}

Our data thus far indicates a significant contribution of mammary epithelial COX-2-derived mediators to protumor immune function, particularly $\mathrm{T}$ lymphocyte and cytotoxic immune cell function, in the tumor microenvironment. We next examined pathways that control $\mathrm{T}$ cell recruitment, activation and function. In breast cancer, tumor cell expression of the chemokines CXCL9 and 10 recruits lymphocytes, improves survival in mouse models and human studies $[29,30]$, and $\mathrm{PGE}_{2}$ inhibits expression of both chemokines in breast cancer cells in vitro [12]. Paraffin embedded sections of WT and $\mathrm{COX}-2^{\mathrm{MEC}} \mathrm{KO}$ tumors showed substantially higher levels of CXCL9 expression, by immunohistochemistry, in $\mathrm{COX}-2^{\mathrm{MEC}} \mathrm{KO}$ tumors, and this staining was evident throughout the tumor cells (Figure 4A). WT tumors, in contrast, showed weak CXCL9 staining (Figure 4A). $\mathrm{T}$ cell activation requires binding of $\mathrm{T}$ cell receptors to antigen and is regulated by a balance of co-stimulatory and co-inhibitory receptor-ligand interactions. $T$ cell CD28 receptor engagement by CD80 or CD86, expressed on antigen presenting cells, provides the additional signal necessary for $\mathrm{T}$ cell activation. The same ligands can, alternatively, drive $\mathrm{T}$ cells to a state of anergy through binding to cytotoxic T lymphocyte antigen 4 (CTLA-4) [31]. Inhibition of $\mathrm{T}$ cell function is also directed through binding of programmed death ligand 1 (PD-L1) to its receptor, $\mathrm{PD}-1$, expressed on the $\mathrm{T}$ cell surface [32]. In our study, gene expression levels for both inhibitory receptors CTLA4 and $\mathrm{PD}-1$, as well as PD-L1, were decreased in COX $-2^{\mathrm{MEC}} \mathrm{KO}$ tumors compared to WT, suggesting suppressed signaling through co-inhibitory pathways (Figure 4B). Both cancer cells and tumor infiltrating myeloid cells are considered as sources of PD-L1 expression in the tumor microenvironment [33,34]. We did not observe any change in PD-L1 mRNA levels in CD $45^{+}$TILs from COX-2 ${ }^{\text {MEC }} \mathrm{KO}$ and WT tumors (data not shown), suggesting that tumor cell PD-L1 was suppressed by COX-2 deficiency. Indeed, NAF COX-2KD, which, compared to NAF nt, grew poorly as orthotopic tumors in immune competent syngenic mice (Figure $5 \mathrm{~B}$ ) also produced substantially less $\mathrm{PD}-\mathrm{L} 1$ protein in response to IFN $\gamma$ (Figure 5C). Interestingly, addition of exogenous $\mathrm{PGE}_{2}$ neither modified PD-L1 expression in NAF nt nor rescued IFN $\gamma$-induced PD-L1 expression in NAF COX-2KD cells.

To assess how critical the loss of COX-2's immune suppressive actions was for reduced tumor growth and burden, we examined growth of NAF COX-2KD orthotopic tumors in recipient mice treated with an anti-CD8 


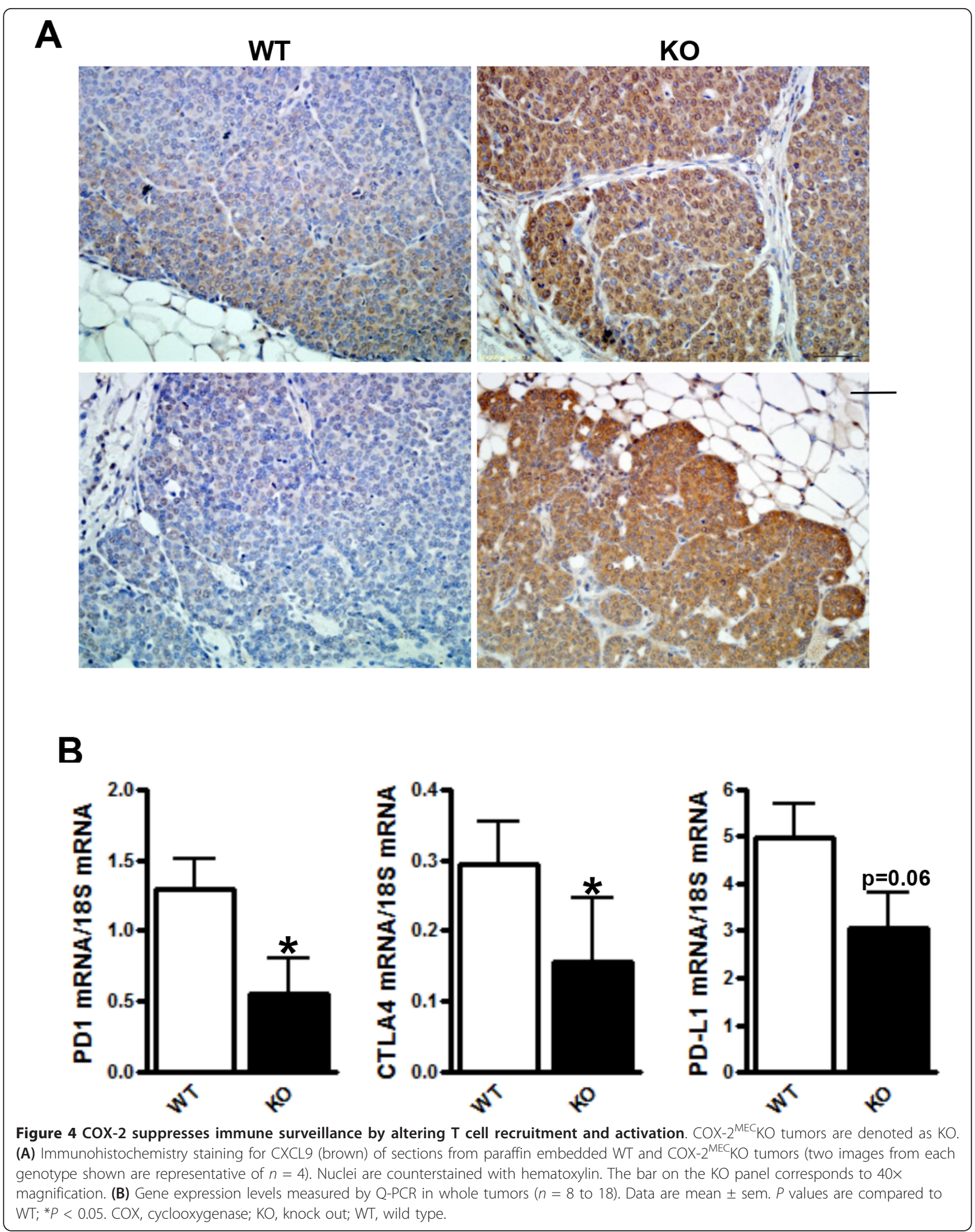




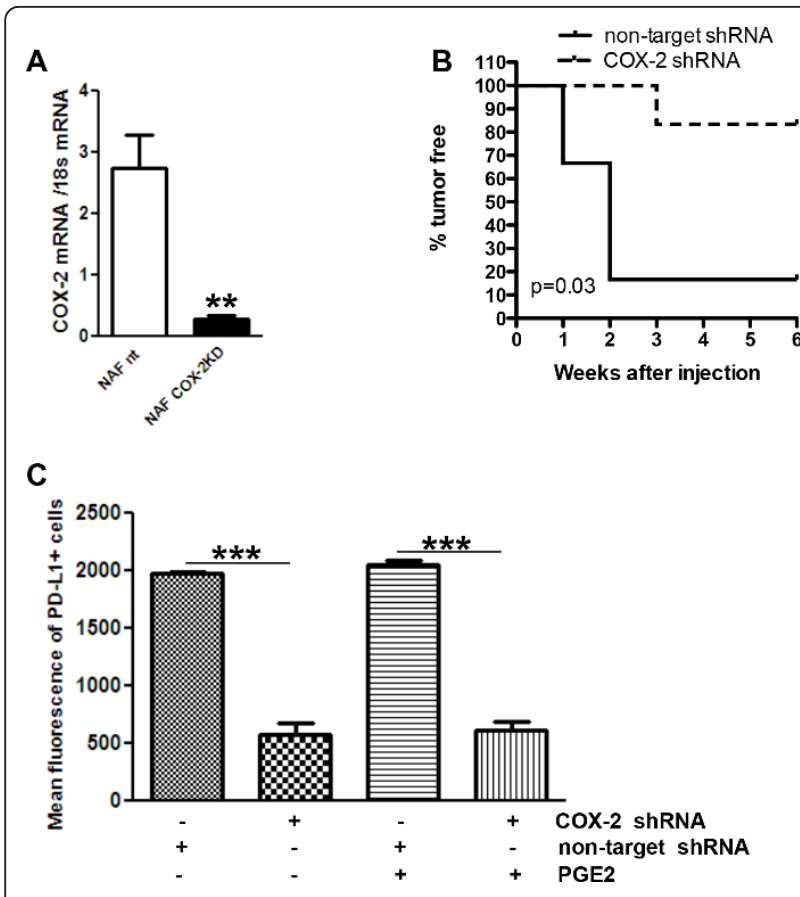

Figure 5 COX-2 knock down reduced tumor cell PD-L1 expression and orthotopic tumor growth. ErbB2-transformed mammary epithelial cells (NAF) were transduced with non-targeted shRNA (NAF nt) or COX-2 targeted shRNA (NAF COX-2KD). (A) COX2 mRNA levels measured by Q-PCR, after 24 hours of treatment with $5 \mu \mathrm{g} / \mathrm{ml}$ LPS $(n=4)$. (B) Percent of tumor free mice after mammary fat pad injection of NAF nt and NAF COX-2KD $(n=6)$. (C) Mean fluorescence of PD-L1 in NAF, measured by flow cytometry, after 48 hours of treatment with $10 \mathrm{ng} / \mathrm{ml} \mathrm{IFN \gamma}$, with or without $250 \mathrm{nM}$ $\mathrm{PGE}_{2}(n=3$ to 6$)$. Data in column graphs are mean \pm sem. $P$ values are compared to NAF nt control, unless otherwise indicated. ${ }^{*} P<$ $0.05,{ }^{*} P<0.005,{ }^{* *} P<0.0005$. COX, cyclooxygenase; $\mathrm{KO}$, knock out; shRNA, short hairpin RNA.

antibody, to deplete $\mathrm{CD}^{+}{ }^{+}$immune cells, or an isotype control antibody. Complete depletion of $\mathrm{CD} 8^{+}$cells in blood was confirmed by flow cytometry (Figure 6A). In isotype control antibody treated mice NAF COX-2KD grew poorly in only two of six injections. In contrast, six of six NAF COX-2KD tumors grew in $\mathrm{CD}^{+}$depleted mice, similar to NAF nt control cells (Figure 6B), and were markedly larger at necroscopy (four weeks after tumor injection; Figure 6C).

\section{Discussion}

Significant attention is now focused on understanding how resident and infiltrating cells in the tumor microenvironment support disease progression and in developing therapeutic strategies directed at microenvironmental targets [7]. Central to the pro-tumor microenvironment is suppression of immune cell function allowing tumor cells to avoid destruction. In the current study, we demonstrated enhanced immune cell recruitment and reduced $\mathrm{T}$ cell co-inhibitory pathways in tumors that lack mammary epithelial expression of the pro-inflammatory enzyme COX-2, coincident with delayed ErbB2 oncogene-driven mammary tumor development.

Consistent with established paradigms of COX-2 in cancer $[6,35,36]$, deletion of MEC COX-2 delayed mammary tumor onset, lowered tumor multiplicity, reduced tumor cell proliferation and decreased tumor vascularization. Reduced vascularization in COX-2 ${ }^{\mathrm{MEC}} \mathrm{KO}$ tumors was associated with lower expression of VEGFA and its receptor VEGFR2, a dominant pro-angiogenic pathway in tumors [37], consistent with the role of COX-2 in promoting the angiogenic switch that allows tumors to progress [38]. It may be that reduced tumor cell proliferation and suppressed angiogenesis associated with deletion of MEC COX-2 was sufficient to suppress tumors. However, the elevation of $\mathrm{CD}^{+}$and $\mathrm{CD}^{+}$immune cell populations we observed in COX-2 ${ }^{\mathrm{MEC}} \mathrm{KO}$ mice, prompted us to consider how tumor cell COX-2 contributes to tumor immune function.

COX-2-mediated promotion of pro-tumorigenic $\mathrm{T}_{\mathrm{h}} 2$ lymphocyte and M2 macrophage functional phenotypes, as well as suppression of cytotoxic immune cell activity, has been reported [6]. However, it remains unclear how COX-2 contributes to the orchestration of immune cell function as tumors develop. In part, the paucity of information reflects the difficulties of working with global COX-2 knock out mice, which have breeding problems, severe renal pathology and a shortened life span [39], none of which are encountered in our targeted COX$2^{\mathrm{MEC}} \mathrm{KO}$ mice, as well as the extensive use of immune deficient host mice for tumor transplant studies. Compared to WT, three populations of immune cells $\mathrm{CD}^{+} \mathrm{CD} 4^{+}$, which are $\mathrm{T}_{\mathrm{h}}$ lymphocytes, $\mathrm{CD}^{+} \mathrm{CD}^{+}$cells, which are CTLs and $\mathrm{CD}^{-} \mathrm{CD} 8^{+}$, which encompass NKs and dendritic cells - were elevated in COX- $2^{\mathrm{MEC}} \mathrm{KO}$ tumors. Within the $\mathrm{CD}^{+} \mathrm{CD}^{+}$population, an increase in anti-tumorigenic $T_{h} 1$ cells may suppress tumors in COX-2 ${ }^{\mathrm{MEC}} \mathrm{KO}$ mice; however, greater activity of $\mathrm{T}_{\mathrm{h}} 2$ lymphocytes and/or $\mathrm{T}_{\text {reg }}$ would be expected to promote tumor growth [24]. The strong trend towards an increased T-bet/GATA3 mRNA ratio, a measure of the $\mathrm{T}_{\mathrm{h}} 1$ to $\mathrm{T}_{\mathrm{h}} 2$ balance [40], and the unchanged expression of FoxP3, a marker for $\mathrm{T}_{\text {reg }}[6,24]$, indicates the likely prevalence of the pro-immune helper function of $T_{h} 1$ lymphocytes over pro-tumorigenic $\mathrm{T}_{\mathrm{h}} 2$ lymphocytes or immune suppressive $\mathrm{T}_{\text {regs }}$, in COX-2 ${ }^{\mathrm{MEC}} \mathrm{KO}$ tumors. These data are consistent with the shift toward type 1 immunity we reported previously in carcinogen-induced mammary tumors in COX $-2^{\mathrm{MEC}} \mathrm{KO}$ mice, which were also delayed compared to WT [17].

Within the $\mathrm{CD}^{+}$populations, the suppressed tumor phenotype in COX-2 ${ }^{\mathrm{MEC}} \mathrm{KO}$ mice may result from increased cytolytic actions of CTLs and NKs [24], as well as enhanced immunogenic actions of mature dentritic 


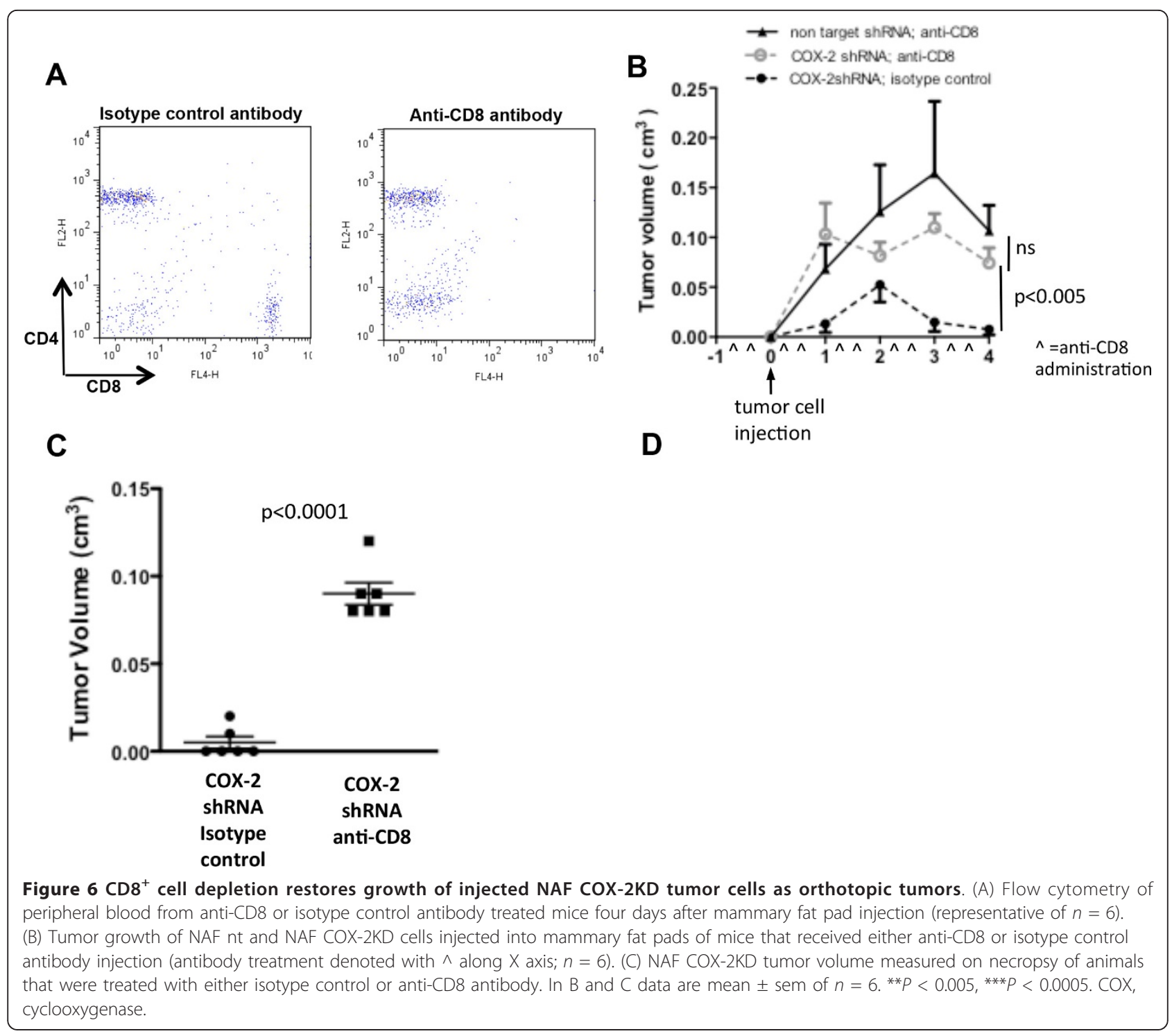

cells [41]. We did not directly discriminate between the relative contributions of these $\mathrm{CD}^{+}$subtypes; however, a key role for $\mathrm{CD}^{+}$immune cells in COX-2-mediated control of tumor immune function is strongly supported by the restoration of NAF COX-2KD tumor cell growth in $\mathrm{CD}^{+}$-depleted mice.

TAM are abundant in mammary tumors and their density is generally directly correlated with disease severity and prognosis $[42,43]$. Similar to the $\mathrm{T}_{h} 1$ and $\mathrm{T}_{\mathrm{h}} 2$ lymphocyte characterization, M1 and M2 macrophages are considered anti- and pro- tumor, respectively [44]. We reported previously that $\mathrm{COX}$-2-derived $\mathrm{PGE}_{2}$ restrains M1 macrophage polarization in vitro and in carcinogeninduced mammary tumors [17]. In the current model, however, CD86, a M1 macrophage marker, was not different in COX-2 ${ }^{\mathrm{MEC}} \mathrm{KO}$ tumor associated $\mathrm{F} 4 / 80^{+}$cells (macrophages) or in isolated CD $45^{+}$TILs, compared to
WT. It is likely that the relevance of COX-2-mediated paracrine control of M1 macrophage function to tumor progression varies between models. Retnla (Resistin-like molecule alpha/FIZZ1), a cytokine derived from alternatively activated M2 type macrophages [45], was significantly lower in CD $45^{+}$TILs from COX-2 ${ }^{\mathrm{MEC}} \mathrm{KO}$ tumors suggesting reduced $\mathrm{M} 2$ polarization, a possible reflection of reduced $\mathrm{T}_{\mathrm{h}} 2$-derived cytokines in the COX-2 ${ }^{\mathrm{MEC}} \mathrm{KO}$ microenvironment and/or loss of paracrine COX-2derived $\mathrm{PGE}_{2}$ activity, which augments $\mathrm{M} 2$ polarization of BMDM in vitro.

As a whole, our analysis of the tumor microenvironment strongly supported a shift towards enhanced helper and effector $\mathrm{T}$ lymphocyte recruitment and function in COX-2 ${ }^{\mathrm{MEC}} \mathrm{KO}$ tumors. It may be that there is simply an increased immune cell recruitment to breast tumors lacking epithelial COX-2. Indeed, we saw a dramatic increase 
in tumor cell expression of the T cell chemokine CXCL9 in $\mathrm{COX}-2^{\mathrm{MEC}} \mathrm{KO}$ tumors, consistent with a recent report in patients with invasive breast cancer that tumor cells are the major source of CXCL9 [12]. In the same study, $\mathrm{PGE}_{2}$ suppressed IFN $\gamma$-induced CXCL9 levels in MCF-7 and MDA-MB 231 breast cancer cells, and COX inhibitors increased CXCL9 secretion. Despite the higher CXCL9 levels in COX- $2^{\mathrm{MEC}} \mathrm{KO}$ tumors, however, the absolute number of $\mathrm{CD}^{+}$cells by flow cytometry was not higher than in WT tumors suggesting a local influence of tumor cell COX-2 derived mediators in limiting immune cell function rather than a simple recruitment effect.

Intense interest in cancer immunotherapy has focused recently on immune checkpoints, whose function to dampen immune responses is important for self tolerance and control of physiological immune responses. Two central and well-studied immune checkpoints are the co-inhibitory receptors CTLA4 and PD-1; antagonists to both are currently in clinical trials for melanoma and other cancers [32]. Engagement of CLTA4 or PD-1 on immune cells by their ligands CD80/CD86 or PD-L1, respectively, can suppress or shut down immune surveillance [46]. Conversely, blockade of co-inhibitory receptor-ligand interaction can enhance anti-tumor immunity [32]. In our study, levels of CTLA4 and PD-1, as well as $\mathrm{PD}-\mathrm{L} 1$, were decreased in COX-2 ${ }^{\mathrm{MEC}} \mathrm{KO}$ tumors. The PD-1-PD-L1 interaction is of particular interest in this regard since PD-1 expression in tissues is induced by inflammatory signals where it acts to suppress $\mathrm{T}$ cell activity and limit collateral tissue damage [32]. We reasoned, therefore, that COX-2, an established inflammatory gene, may act in tumors to upregulate expression of PD-1/PD-L1, thereby suppressing immune function and facilitating immune escape. In support of this hypothesis, NAF COX-2KD, which grew very poorly as orthotopic tumors, generated substantially less PD-L1 in response to IFN $\gamma$ compared to NAF nt control cells. The failure of exogenous $\mathrm{PGE}_{2}$ to restore PD-L1 expression levels in NAF COX-2KD may suggest distinct actions of autocrine and paracrine $\mathrm{PGE}_{2}$, or indicate a role for other COX-2-derived products, in tumor cell COX-2 mediated control of PD-1 expression. The pathways through which $\mathrm{COX}$-2-derived $\mathrm{PGE}_{2}$ /other prostanoids control tumor cell expression of PD-L1 and other immune modulators are currently under investigation.

Our study provides significant insight into the complex autocrine and paracrine functions of mammary epithelial COX-2 in ErbB2-induced breast cancer and suggests that tumor cell COX-2 is an important component in establishing a permissive immune microenvironment. Recent studies indicated that $\mathrm{CD}^{+}$tumor infiltration bolstered chemotherapeutic responses in human breast cancer and mouse models [8]. Our demonstration that deletion of tumor cell COX-2 can enhance tumor-associated $\mathrm{CD} 8^{+}$ cytotoxic immune cell infiltration and function may open new avenues to develop targeted strategies for COX-2 inhibition in combination with cytotoxic drugs. Further, there have been significant advances in cancer immunotherapy using antibodies to block CTLA4 or PD-1 coinhibitory function, thereby augmenting anti-tumor immunity [32,47-49]. To our knowledge, our study is the first to link COX-2 to T cell co-inhibitory receptor/ligand function, a potentially new avenue to investigate COX-2 inhibitors as adjuvants to immunotherapy. Finally, we demonstrated that interruption of COX-2 function selectively in epithelial cells was sufficient to reduce ErbB2(this study) and carcinogen [17] induced mammary tumorigenesis and growth. The clinical use of systemic COX-2 inhibitors in cancer, although supported across multiple studies [1], is limited by the associated gastrointestinal and cardiovascular hazards [50]. We speculate that, as improved targeted drug delivery modalities continue to emerge, delivery of COX-2 selective inhibitors directly to the tumor cells may allow for safe and effective use of these drugs in cancer without the deleterious side effects associated with systemic COX inhibition.

\section{Conclusions}

The data strongly support that, in addition to its angiogenic function, tumor cell COX-2-derived mediators suppress anti-tumor immune cell function, possibly through upregulation of inhibitory immune checkpoints, contributing to tumor immune escape. COX-2 inhibition may be clinically useful to augment breast cancer immunotherapy.

\section{Abbreviations}

BMDM: bone marrow derived macrophages; BSA: bovine serum albumin; COX: cycloogygenase; CTL: cytotoxic T lymphocyte; CTLA-4: cytotoxic T lymphocyte antigen 4; (D)MEM: (Dulbecco's) modified Eagle's medium; EDTA: ethylenediaminetetraacetic acid; FACS: fluorescence-activated cell sorting; FBS: fetal bovine serum; IFN: interferon; KO: knock out; KD: knock down; MEC: mammary epithelial cell; mmtv: mouse mammary tumor virus; NK: natural killer cells; nt: non-target; PCR: polymerase chain reaction; PD-1: programed death 1; PD-L1: programmed death ligand 1; PG: prostaglandin; shRNA: small hairpin RNA; TAM: tumor associated macrophage; TIL: tumor infiltrating leukocyte; TNF-a: tumor necrosis factor-a; WT: wild type.

\section{Competing interests}

The authors declare that they have no competing interests.

\section{Authors' contributions}

NM made substantial contributions to the study design, data acquisition, analysis and interpretation, as well as the writing and editing, of the manuscript. EPC contributed to data acquisition and analysis in the macrophage and flow cytometry experiments. RAE contributed to the design of the immune depletion experiments. VN contributed to the data acquisition. RHV contributed to the analysis and interpretation of the immune function data. EMS directed the conception and design of the study and the experimental work, contributed to the analysis and interpretation of data and critically revised the manuscript for important intellectual content. All authors read and approved the final manuscript. 


\section{Acknowledgements}

We thank Dr Lewis Chodosh for supplying the NAF mammary tumor cells. This work was supported by American Cancer Society grants RSG0802401 (to EMS), PF-11-226-01-CSM (to NM), by the National Institutes of Health training grant T32-GM08076 (EPC) and by a grant from the Breast Cancer Research Foundation (RHV)

\section{Authors' details}

'Institute for Translational Medicine and Therapeutics, Smilow Center for Translational Research, 3400 Civic Center Blvd, Philadelphia, PA 19104, USA. ${ }^{2}$ Abramson Family Cancer Research Institute, 421 Curie Blvd, Philadelphia, PA 19104, USA. ${ }^{3}$ Department of Medicine, Perelman School of Medicine at the University of Pennsylvania, 415 Curie Blvd, Philadelphia, PA 19104, USA.

Received: 10 December 2012 Revised: 31 May 2013

Accepted: 8 July 2013 Published: 3 September 2013

\section{References}

1. Harris RE: Cyclooxygenase-2 (cox-2) blockade in the chemoprevention of cancers of the colon, breast, prostate, and lung. Inflammopharmacology 2009, 17:55-67.

2. Howe LR: Inflammation and breast cancer. Cyclooxygenase/ prostaglandin signaling and breast cancer. Breast Cancer Res 2007, 9:210

3. Howe LR, Chang SH, Tolle KC, Dillon R, Young LJ, Cardiff RD, Newman RA, Yang P, Thaler HT, Muller WJ, Hudis C, Brown AM, Hla T, Subbaramaiah K, Dannenberg AJ: HER2/neu-induced mammary tumorigenesis and angiogenesis are reduced in cyclooxygenase-2 knockout mice. Cancer Res 2005, 65:10113-10119.

4. Lanza-Jacoby S, Miller S, Flynn J, Gallatig K, Daskalakis C, Masferrer JL, Zweifel BS, Sembhi H, Russo IH: The cyclooxygenase-2 inhibitor, celecoxib, prevents the development of mammary tumors in Her-2/neu mice. Cancer Epidemiol Biomarkers Prev 2003, 12:1486-1491.

5. Harris RE, Beebe-Donk J, Alshafie GA: Reduction in the risk of human breast cancer by selective cyclooxygenase-2 (COX-2) inhibitors. BMC Cancer 2006, 6:27.

6. Wang D, Dubois RN: Eicosanoids and cancer. Nat Rev Cancer 2010, 10:181-193.

7. Hanahan D, Weinberg RA: Hallmarks of cancer: the next generation. Cell 2011, 144:646-674

8. DeNardo DG, Brennan DJ, Rexhepaj E, Ruffell B, Shiao SL, Madden SF, Gallagher WM, Wadhwani N, Keil SD, Junaid SA, rugo HS, Hwang ES, Jirström K, West BL, Coussens LM: Leukocyte complexity predicts breast cancer survival and functionally regulates response to chemotherapy. Cancer Discov 2011, 1:54-67.

9. DeNardo DG, Andreu P, Coussens LM: Interactions between lymphocytes and myeloid cells regulate pro- versus anti-tumor immunity. Cancer Metastasis Rev 2010, 29:309-316.

10. Finak $G$, Bertos $N$, Pepin $F$, Sadekova $S$, Souleimanova $M$, Zhao $H$, Chen $H$, Omeroglu G, Meterissian S, Omeroglu A, Hallett M, Park M: Stromal gene expression predicts clinical outcome in breast cancer. Nat Med 2008, 14:518-527.

11. Obermajer N, Muthuswamy R, Odunsi K, Edwards RP, Kalinski P: PGE(2)induced CXCL12 production and CXCR4 expression controls the accumulation of human MDSCs in ovarian cancer environment. Cancer Res 2011, 71:7463-7470.

12. Bronger H, Kraeft S, Schwarz-Boeger U, Cerny C, Stockel A, Avril S, Kiechle M, Schmitt M: Modulation of CXCR3 ligand secretion by prostaglandin E2 and cyclooxygenase inhibitors in human breast cancer. Breast Cancer Res 2012, 14:R30.

13. Chattopadhyay S, Bhattacharyya S, Saha B, Chakraborty J, Mohanty S, Sakib Hossain DM, Banerjee S, Das K, Sa G, Das T: Tumor-shed PGE(2) impairs IL2Rgammac-signaling to inhibit CD4 T cell survival: regulation by theaflavins. PLoS One 2009, 4:e7382.

14. Pockaj BA, Basu GD, Pathangey LB, Gray RJ, Hernandez UL, Gendler SJ, Mukherjee P: Reduced T-cell and dendritic cell function is related to cyclooxygenase-2 overexpression and prostaglandin E2 secretion in patients with breast cancer. Ann Surg Oncol 2004, 11:328-339.

15. Sinha P, Clements VK, Fulton AM, Ostrand-Rosenberg S: Prostaglandin E2 promotes tumor progression by inducing myeloid-derived suppressor cells. Cancer Res 2007, 67:4507-4513.
16. Kojima M, Morisaki T, Uchiyama A, Doi F, Mibu R, Katano M, Tanaka M: Association of enhanced cyclooxygenase-2 expression with possible local immunosuppression in human colorectal carcinomas. Ann Surg Oncol 2001, 8:458-465.

17. Markosyan N, Chen EP, Ndong VN, Yao Y, Sterner CJ, Chodosh LA Lawson JA, Fitzgerald GA, Smyth EM: Deletion of cyclooxygenase 2 in mouse mammary epithelial cells delays breast cancer onset through augmentation of type 1 immune responses in tumors. Carcinogenesis 2011, 32:1441-1449.

18. Iwamoto A, Ikeguchi M, Matsumoto $S$, Hukumoto $Y$, Inoue $M$, Ozaki $T$, Ataka M, Tanida T, Endo K, Katano K, Hirooka Y: Tumor cyclooxygenase-2 gene suppresses local immune responses in patients with hepatocellular carcinoma. Tumori 2006, 92:130-133.

19. Stolina M, Sharma S, Lin Y, Dohadwala M, Gardner B, Luo J, Zhu L, Kronenberg M, Miller PW, Portanova J, Lee JC, Dubinett SM: Specific inhibition of cyclooxygenase 2 restores antitumor reactivity by altering the balance of IL-10 and IL-12 synthesis. J Immunol 2000, 164:361-370.

20. Hamanishi J, Mandai M, Abiko K, Matsumura N, Baba T, Yoshioka Y, Kosaka K, Konishi I: The comprehensive assessment of local immune status of ovarian cancer by the clustering of multiple immune factors. Clin Immunol 2011, 141:338-347.

21. Specht $C$, Bexten $S$, Kolsch E, Pauels HG: Prostaglandins, but not tumorderived IL-10, shut down concomitant tumor-specific CTL responses during murine plasmacytoma progression. Int J Cancer 2001, 91:705-712.

22. Betz M, Fox BS: Prostaglandin E2 inhibits production of Th1 lymphokines but not of Th2 lymphokines. J Immunol 1991, 146:108-113.

23. Kalinski P: Regulation of immune responses by prostaglandin E2. J Immunol 2012, 188:21-28.

24. Ruffell B, DeNardo DG, Affara NI, Coussens LM: Lymphocytes in cancer development: polarization towards pro-tumor immunity. Cytokine Growth Factor Rev 2010, 21:3-10.

25. Borowsky AD: Choosing a mouse model: experimental biology in context-the utility and limitations of mouse models of breast cancer. Cold Spring Harb Perspect Biol 2011, 3:a009670.

26. Ross JS, Fletcher JA: The HER-2/neu oncogene in breast cancer: prognostic factor, predictive factor, and target for therapy. Stem Cells 1998, 16:413-428.

27. Ursini-Siegel J, Schade B, Cardiff RD, Muller WJ: Insights from transgenic mouse models of ERBB2-induced breast cancer. Nat Rev Cancer 2007, 7:389-397.

28. Sinha P, Clements VK, Ostrand-Rosenberg S: Reduction of myeloid-derived suppressor cells and induction of M1 macrophages facilitate the rejection of established metastatic disease. J Immunol 2005, 174:636-645.

29. Specht K, Harbeck N, Smida J, Annecke K, Reich U, Naehrig J, Langer R, Mages J, Busch R, Kruse E, Klein-Hitpass L, Schmitt M, Kiechle M, Hoefler H: Expression profiling identifies genes that predict recurrence of breast cancer after adjuvant CMF-based chemotherapy. Breast Cancer Res Treat 2009, 118:45-56.

30. Walser TC, Ma X, Kundu N, Dorsey R, Goloubeva O, Fulton AM: Immunemediated modulation of breast cancer growth and metastasis by the chemokine Mig (CXCL9) in a murine model. J Immunother 2007, 30:490-498.

31. Chen L: Co-inhibitory molecules of the B7-CD28 family in the control of T-cell immunity. Nat Rev Immunol 2004, 4:336-347.

32. Pardoll DM: The blockade of immune checkpoints in cancer immunotherapy. Nat Rev Cancer 2012, 12:252-264.

33. Dong H, Strome SE, Salomao DR, Tamura H, Hirano F, Flies DB, Roche PC, Lu J, Zhu G, Tamada K, Lennon VA, Celis E, Chen L: Tumor-associated B7-H1 promotes T-cell apoptosis: a potential mechanism of immune evasion. Nat Med 2002, 8:793-800.

34. Kuang DM, Zhao Q, Peng C, Xu J, Zhang JP, Wu C, Zheng L: Activated monocytes in peritumoral stroma of hepatocellular carcinoma foster immune privilege and disease progression through PD-L1. J Exp Med 2009, 206:1327-1337.

35. Gately S, Li WW: Multiple roles of COX-2 in tumor angiogenesis: a target for antiangiogenic therapy. Semin Oncol 2004, 31:2-11.

36. Karnezis T, Shayan R, Caesar C, Roufail S, Harris NC, Ardipradja K, Zhang YF, Williams SP, Farnsworth RH, Chai MG, Rupasinghe TW, Tull DL, Baldwin ME, Sloan EK, Fox SB, Achen MG, Stacker SA: VEGF-D promotes tumor metastasis by regulating prostaglandins produced by the collecting lymphatic endothelium. Cancer Cell 2012, 21:181-195. 
37. Hicklin DJ, Ellis LM: Role of the vascular endothelial growth factor pathway in tumor growth and angiogenesis. J Clin Oncol 2005, 23:1011-1027.

38. Chang SH, Liu CH, Conway R, Han DK, Nithipatikom K, Trifan OC, Lane TF, Hla T: Role of prostaglandin E2-dependent angiogenic switch in cyclooxygenase 2-induced breast cancer progression. Proc Natl Acad Sci USA 2004, 101:591-596.

39. Yang T, Huang YG, Ye W, Hansen P, Schnermann JB, Briggs JP: Influence of genetic background and gender on hypertension and renal failure in COX-2-deficient mice. Am J Physiol Renal Physiol 2005, 288:F1125-1132.

40. Jenner RG, Townsend MJ, Jackson I, Sun K, Bouwman RD, Young RA, Glimcher LH, Lord GM: The transcription factors T-bet and GATA-3 control alternative pathways of T-cell differentiation through a shared set of target genes. Proc Natl Acad Sci USA 2009, 106:17876-17881.

41. Palucka K, Banchereau J: Cancer immunotherapy via dendritic cells. Nat Rev Cancer 2012, 12:265-277.

42. Luo Y, Zhou H, Krueger J, Kaplan C, Lee SH, Dolman C, Markowitz D, Wu W Liu C, Reisfeld RA, Xiang R: Targeting tumor-associated macrophages as a novel strategy against breast cancer. J Clin Invest 2006, 116:2132-2141.

43. Ruffell B, Affara NI, Coussens LM: Differential macrophage programming in the tumor microenvironment. Trends Immunol 2012, 33:119-126.

44. Sica A, Mantovani A: Macrophage plasticity and polarization: in vivo veritas. J Clin Invest 2012, 122:787-795.

45. Nair MG, Du Y, Perrigoue JG, Zaph C, Taylor JJ, Goldschmidt M, Swain GP, Yancopoulos GD, Valenzuela DM, Murphy A, Karow M, Stevens S, Pearce EJ, Artis D: Alternatively activated macrophage-derived RELM-\{alpha\} is a negative regulator of type 2 inflammation in the lung. J Exp Med 2009, 206:937-952.

46. Zou W: Immunosuppressive networks in the tumour environment and their therapeutic relevance. Nat Rev Cancer 2005, 5:263-274.

47. Curran MA, Montalvo W, Yagita H, Allison JP: PD-1 and CTLA-4 combination blockade expands infiltrating $T$ cells and reduces regulatory $\mathrm{T}$ and myeloid cells within B16 melanoma tumors. Proc Natl Acad Sci USA 2010, 107:4275-4280.

48. Topalian SL, Hodi FS, Brahmer JR, Gettinger SN, Smith DC, McDermott DF, Powderly JD, Carvajal RD, Sosman JA, Atkins MB, Leming PD, Spigel DR, Antonia SJ, Horn L, Drake CG, Pardoll DM, Chen L, Sharfman WH, Anders RA, Taube JM, McMiller TL, Xu H, Korman AJ, Jure-Kunkel M, Agrawal S, McDonald D, Kollia GD, Gupta A, Wigginton JM, Sznol M: Safety, activity, and immune correlates of anti-PD-1 antibody in cancer. N Engl J Med 2012, 366:2443-2454.

49. Brahmer JR, Tykodi SS, Chow LQ, Hwu WJ, Topalian SL, Hwu P, Drake CG, Camacho LH, Kauh J, Odunsi K, Pitot HC, Hamid O, Bhatia S, Martins, R, Eaton K, Chen S, Salay TM, Alaparthy S, Grosso JF, Korman AJ, Parker SM, Agrawal S, Goldberg SM, Pardoll DM, Gupta A, Wigginton JM: Safety and activity of anti-PD-L1 antibody in patients with advanced cancer. N Engl J Med 2012, 366:2455-2465.

50. Grosser T, Yu Y, Fitzgerald GA: Emotion recollected in tranquility: lessons learned from the COX-2 saga. Annu Rev Med 2010, 61:17-33.

doi:10.1186/bcr3469

Cite this article as: Markosyan et al: Mammary Carcinoma Cell Derived Cyclooxygenase 2 Suppresses Tumor Immune Surveillance by Enhancing Intratumoral Immune Checkpoint Activity. Breast Cancer Research 201315 R75.

\section{Submit your next manuscript to BioMed Central and take full advantage of:}

- Convenient online submission

- Thorough peer review

- No space constraints or color figure charges

- Immediate publication on acceptance

- Inclusion in PubMed, CAS, Scopus and Google Scholar

- Research which is freely available for redistribution 